\title{
Klor Dioksitin Buğday (Triticum aestivum L.) Köklerindeki Fizyolojik ve Biyokimyasal Süreçler Üzerine Etkisi
}

\section{Zeynep Sezer ${ }^{1}$, Nevzat Esim²}

${ }^{1}$ Bingöl Üniversitesi, Fen Edebiyat Fakültesi, Moleküler Biyoloji ve Genetik Bölümü, Bingöl, Türkiye. orcid.org/0000-0002-8208-66072

${ }^{2}$ Bingöl Üniversitesi, Fen Edebiyat Fakültesi, Moleküler Biyoloji ve Genetik Bölümü, Bingöl, Türkiye. orcid.org/0000-0001-5121-092X

*Corresponding author: nesim@bingol.edu.tr

Received: 11 May 2021, Accept: 24 May 2021, Published Online: 01 June 2021

Öz

Bu çalışmada farklı konsantrasyonlardaki (50 ve $100 \mathrm{mg} / \mathrm{L}$ ) klor dioksitin $\left(\mathrm{ClO}_{2}\right)$ çimlenme aşamasında buğday bitkisinin kök bölgesindeki fizyolojik ve biyokimyasal süreçler üzerindeki etkisi araştırılmıştır. Fizyolojik parametreler olarak çimlenme oranı, kök uzunluğu ve kök yaş-kuru ağırıkları incelenirken biyokimyasal parametreler olarak da lipid peroksidasyon oranı, reaktif oksijen türleri ve antioksidan enzim aktiviteleri incelenmiştir. Kullanılan her $\mathrm{iki}^{\mathrm{ClO}_{2}}$ konsantrasyonu çimlenme oranında inhibisyona neden olmazken kök uzunluğu ve yaş-kuru ağırlık oranlarında ise artışa neden olmuştur. Her iki $\mathrm{ClO}_{2}$ konsantrasyonu lipid peroksidayonun bir indikatörü olan malondialdehit (MDA) oranını azaltmış, hidrojen peroksit miktarını etkilememiş ve süperoksit anyonu oranında konsantrasyona bağı olarak değişime neden olmuştur. Benzer şekilde $\mathrm{ClO}_{2}$ uygulamaları süperoksit dismutaz (SOD) aktivitesini artıııken, peroksidaz (POD) aktivitesini ise azaltmıştır. Tüm sonuçlar birlikte değerlendirildiğinde suların dezenfeksiyonunda kullanılan ve tarımsal sulara da karışan $\mathrm{ClO}_{2}$ 'in buğday bitkisinin çimlenme aşamasında herhangi bir inhibisyona ve oksidatif hasara neden olmadığı anlaşılmaktadır.

Anahtar kelimeler: Buğday, Çimlenme, Klor dioksit, Oksidatif hasar

Effect of Chlorine Dioxide on Physiological and Biochemical Processes in Wheat (Triticum aestivum L.) Roots

\section{Abstract}

In this study, the effect of chlorine dioxide $\left(\mathrm{ClO}_{2}\right)$ at different concentrations (50 and $100 \mathrm{mg} / \mathrm{L}$ ) on the physiological and biochemical processes in the root of the wheat plant during the germination stage was investigated. While germination rate, root length and root wet-dry weights were examined as physiological parameters, lipid peroxidation rate, reactive oxygen species and antioxidant enzyme activities were examined as biochemical 
parameters. While both $\mathrm{ClO}_{2}$ concentrations used did not cause inhibition in the germination rate, they caused an increase in root length and wet-dry weight ratios. Both $\mathrm{ClO}_{2}$ concentrations decreased the ratio of malodialdehyde (MDA), which is an indicator of lipid peroxidation, did not affect the amount of hydrogen peroxide, and the superoxide anion ratio caused a change depending on the concentration. Similarly, $\mathrm{ClO}_{2}$ applications increased superoxide dismutase (SOD) activity and decreased peroxidase (POD) activity. When all the results are evaluated together, it is understood that $\mathrm{ClO}_{10}$, which is used in the disinfection of water and mixed with agricultural water, does not cause any inhibition and oxidative damage during the germination stage of the wheat plant.

Keywords: Wheat, Germination, Chlorine dioxide, Oxidative damage

\section{Giriş}

Tarımsal üretim süreçlerinde sulama için kullanılan su, sıklıkla yeniden kullanılmak üzere tutulur veya açık su sistemlerinden elde edilir. Yeniden kullanım su kaynaklarının verimli kullanımını sağlar, çevreyi besin maddesi ve pestisit akışından korur ve su satın alma ile ilişkili üretim maliyetlerini düşürür (Stewart-Wade, 2011; Hong, 2014; Scarlett vd., 2016). Bununla birlikte, tarımsal üretim süreçlerinde suyun yeniden kullanılması bitki hastalığı riskini artırabilir (Hong ve Moorman, 2005). Bu tür suyun yeniden kullanılması veya geri dönüştürülmesi, bitki patojenlerini su kaynağına sokarak potansiyel olarak enfeksiyonla ilişkili risk, hastalık vakası ve üretim kaybına neden olabilir. Nitekim yapılan bazı çalışmalarda; sönümlenme, kök çürükleri, sürgün ölümü ve yaprak yanıklığı gibi hastalıklardan sorumlu olan Fusarium spp., Colletotrichum spp, Phytophthora spp. ve Pythium spp. gibi bir dizi bitki patojeninin ortaya çıkabileceğini ve sulama suyundan yayılabileceğini belirtilmiştir (Fisher, 2011; Yang vd., 2013; Scarlett vd., 2016). Tarımsal sulamada kullanılan su kaynakları bitki patojenleri için etkili üreme ve yayma sistemleri haline gelebilir. Bu nedenle, sulama için geri dönüştürülmüş suyun dezenfeksiyonu, bitki hastalığının gelişme riskini azaltmak için bitki sağlığı açısından son derece önemlidir.

Suların dezenfeksiyonunda oksitleyici maddeler, filtreleme, ultraviyole radyasyon (UV) ve Isıl işlem dahil olmak üzere pek çok yöntem kullanılmaktadır. Klor dioksit $\left(\mathrm{ClO}_{2}\right)$ patojenler dahil organik maddeyi oksitleyerek dezenfektan görevi görür. Klor dioksit, suda çözünmüş bir gaz olarak bulunur ve hipoklorit tuzlarından daha yüksek bir oksitleme gücüne sahiptir. Newman (2004) klor dioksitin dezenfektan olarak sodyum hipokloritten en az 1.2 kat daha etkili olduğunu bildirmektedir. Klor gibi, klor dioksit de sudaki organik maddenin varlığından etkilenir, ancak daha geniş bir pH aralığında (4-10) etkilidir. $\mathrm{ClO}_{2}$, çok çeşitli mikroorganizmaları etkili bir şekilde etkisiz hale getiren fungisidal, bakterisidal ve virisidal özelliklere sahip olduğu uzun süredir bilinmektedir (Gómez-López vd., 2009; Wang vd., 2019). Bu nedenle, $\mathrm{ClO}_{2}$, karantina prosedürleri, tıbbi, tarımsal ve endüstriyel sterilizasyon önlemleri, gıda muhafazası gibi birçok alanda yaygın olarak uygulanmaktadır. Meyve ve sebzelerin sanitasyon prosedürlerinde kullanımı Dünya Sağlık Örgütü tarafından tavsiye edilmektedir. Bu nedenle Çin ve ABD gibi çeşitli ülkelerde yasal olarak kullanımına izin verilmiştir. $\mathrm{ClO}_{2}$ uygulamasının $(8.0 \mathrm{mg} / \mathrm{L})$ yaban mersini, ahududu ve çileklerde maya ve küf popülasyonlarını azaltmada etkili olduğu gösterilmiştir (Gómez-López vd., 2009; Wang vd., 2019). 
Ekim alanı açısından hem dünyada hem de ülkemizde en fazla ekilen tarım ürünü buğdaydır (Anonim, 2013). 2019 yılı verilerine göre Dünya da ve Türkiye de sırasıyla 762 milyon ve 19 milyon ton buğday üretilmiştir. Türkiye buğday ekim alanı bakımından dünya buğday ekim alanının \%3.1'ini oluşturmaktadır. Bitki hastalıkları ile mücadele buğday yetiştiriciliğinin en önemli konulardan birisidir. Buğday üretim süreçlerinde Fusarium türlerinin neden olduğu ekonomik kayıplar oldukça fazladır. Kök ve kök boğazı hastalıkları, sap hastalıkları, çökerten ve başak yanıkıkları gibi hastalıklar yaygın olarak görülmektedir (Parry vd., 1995).

Bu çalışmanın temel amacı, buğday fidelerinin (Triticium aestivum L.) çimlenmesi, büyümesi ve oksidatif metabolizması üzerine suların dezenfeksiyonunda kullanılan $\mathrm{ClO}_{2}$ 'nin etkilerinin fizyolojik ve biyokimyasal parametreler açısından değerlendirilmesidir.

\section{Materyal ve Metot}

\subsection{Bitki yetiştirilmesi ve uygulamaların yapılması}

Çalışmada buğday (Triticum aestivum L.- Gerek 79) tohumları kullanılmıştır. Buğday bitkisine ait tohumlar, ekimden önce etanol (\%96) ile kısa süreli hızlıca yıkanmış ve \%2'lik sodyum hipoklorit içerisinde $5 \mathrm{dk}$. yüzey sterilizasyonuna tabi tutulmuştur. Daha sonra 5 kez saf su ile yıkanan tohumlar ön denemelerle belirlenen 50 ve $100 \mathrm{mg} / \mathrm{L} \mathrm{ClO}{ }_{2}$ çözeltisinde karanlık bir ortamda ve oda sıcaklı̆ında $30 \mathrm{dk}$ bekletilerek çözeltilerin emdirilmeleri sağlanmıştır. Tohumlar çözeltilerden süzülerek alınmış ve saf su içerisinde çimlendirilmeye bırakılmıştır. Kontrol grubuna ait tohumlar saf su ile emdirilmiştir. Ekim işlemlerinden sonra petri kaplarında karanlık bir ortamda 5 gün boyunca bitkilerin çimlendirilmesi sağlanmıştır. Çimlendirilen buğday tohumlarında hasat yapılmış ve çimlenme oranları, kök uzunluk-ağırlık oranları, lipid peroksidasyon, reaktif oksijen türleri ve antioksidan enzim aktiviteleri incelenmişsir.

\section{2. Çimlenme oranlarının belirlenmesi (\%)}

Buğday bitkisi tohumlarının yüzey sterilizasyonu yapılarak kontrol ve değişik konsantrasyonlarda $\mathrm{ClO}_{2}$ uygulaması yapılarak her gün çimlenme oranları takip edilmiştir. 5. Günün sonunda bu tohumların \% çimlenme oranları belirlenmiştir.

\subsection{Kök-gövde uzunluğu ile yaş-kuru ağırlık belirleme}

Hasat edilen fidelerin kök ve gövde uzunlukları ölçülerek ortalama kök ve gövde uzunlukları belirlendikten sonra bu bitki kısımları tartılarak yaş ağırıkları belirlenmiş daha sonra 1 gün boyunca $60^{\circ} \mathrm{C}$ 'de etüvde bekletilerek hassas terazide kuru ağırlıkları belirlenmiştir.

\subsection{Lipid peroksidasyon aktivitesinin belirlenmesi}

Belirli oranda tartımı (0.5 g) yapılan buğday bitkisinin kök kısımları TCA (\%5) içerisinde homojenize edildi ve santrifüjlendi (10.000 x g'de 15 dakika boyuınca). Süpernatant alındı ve TBA (\%0.5) ilave edildi. Tüplerde reaksiyon kaynar suda 30 dakika inkübe edildikten sonra buz banyosuna alındı. Daha sonra süpernatant alındı ve sırasıyla 532 ve $600 \mathrm{~nm}$ de spektrofotometrede absorbans değerleri okundu. Malondialdehit (MDA) miktarı 
hesaplaması için $1 \mathrm{ml}$ çözeltideki MDA (nmol/ml): [(A532-A600)/155000] x106 formülü kullanıldı (Ananieva vd., 2002).

\subsection{Hidrojen peroksit $\left(\mathrm{H}_{2} \mathrm{O}_{2}\right)$ miktarının belirlenmesi}

Tartımı yapılan numune $(0.2 \mathrm{~g})$ soğuk aseton $(10 \mathrm{~mL})$ da homojenize edildi ve santrifüj yapıldı. Gerekli reaksiyonlar yapıldıktan sonra 415 nm'de spektrofotmetrede absorbansı ölçüldü. Bu ortalama absorbans değerleri, daha önceden hazırlanmış standart grafik yardımıyla nanogram cinsinden $\mathrm{H}_{2} \mathrm{O}_{2}$ miktarına dönüştürüldü. Hesaplamalar ng /g doku olarak yapıldı (Esim, 2011).

\subsection{Süperoksit anyonu miktarının belirlenmesi}

Tartımı yapılan bitki kısmı fosfat tamponunda homojenize edildi ve daha sonar santrifüj edildi. Süpernatanttan $1 \mathrm{ml}$ alındı üzerine $0.1 \mathrm{ml}$ hacimde $10 \mathrm{mM}$ hydroxylamine hydrochloride ve fosfat tamponu eklenerek karıştırıldı. Karışım oda sıcaklığında 20 dakika inkübe edildi ve daha sonra $1 \mathrm{ml}$ alındı ve üzerine $1 \mathrm{ml}$ $17 \mathrm{mM}$ aminobenzene sulfonic acid ve $1 \mathrm{ml}$ hacimde $17 \mathrm{mM}$ 1-naphtylamin eklendi ve karıştıııldı. Son hacimde üzerine $3 \mathrm{ml} \mathrm{n-butyl} \mathrm{alcohol} \mathrm{eklenerek} 530 \mathrm{~nm}$ de spektrofotometrede absorbansları ölçüldü. Hesaplamalar hazırlanan sodyum nitrit standart grafiğine bakılarak yapıldı (Liu vd., 2007).

\subsection{Antioksidan enzim aktivitelerinin belirlenmesi}

$0.5 \mathrm{~g}$ doku tartılarak porselen havan içerisine konulduktan sonra üzerine $5 \mathrm{~mL}$ soğuk homojenat tamponu (\%1 PVP ve $1 \mathrm{mM}$ EDTA ihtiva eden $0.1 \mathrm{M} \mathrm{KH}_{2} \mathrm{PO}_{4} \mathrm{pH}: 7.0$ ) ilave edildi ve karışım bir santrifüj tüpüne aktarılarak $15000 \times \mathrm{g}$ ve $+4^{\circ} \mathrm{C}$ 'de 15 dakika santrifüj edildi. Santrifüj işlemi sonucunda elde edilen süpernatant antioksidan enzimlerin aktivite ölümleri için kaynak olarak kullanıldı (Angelini vd., 1990).

\subsection{Peroksidaz aktivitesinin belirlenmesi}

Peroksidaz (POD) aktivite tayini, guaikol ve $\mathrm{H}_{2} \mathrm{O}_{2}$ 'nin substrat olduğu reaksiyonun ürünü olan renkli bileşiğin meydana getirdiği absorbans artışının 470 nm'de izlenmesi esasına dayanmaktadır (Angelini vd., 1990). Aktivite ölçümü için spektrofotometre küvetine; $100 \mathrm{~mL} 0.1 \mathrm{M}, \mathrm{NaH}_{2} \mathrm{PO}_{4}(\mathrm{pH}: 5.5)$ ve $5 \mathrm{mM}$ guaikol içeren substrat çözeltisinden $3 \mathrm{~mL}$ konulduktan sonra, üzerine $10 \mu \mathrm{L}$ enzim ekstraktı ilave edilir. 470 nm'de 5 dakika boyunca absorbans artışı 1 dakika aralıklarla kaydedilir ve absorbansın doğrusal olarak artığı kısımdaki absorbans artışı 1 dakikaya oranlanır. $25^{\circ} \mathrm{C}$ 'de 1 dakikada, absorbansı 0.01 artıran enzim miktarı $1 \mathrm{EU}$ olarak kabul edilir ve sonuçlar g yaprak başına düşen enzim ünitesi (U. $\mathrm{g}^{-1}$ taze ağırlık) olarak sunulur.

\subsection{Süperoksid dismutaz aktivitesinin belirlenmesi}

Süperoksid dismutaz (SOD) aktivitesi, nitro blue tetrazoliumun (NBT) süperoksit radikalleri ile mavi renkli formazona fotokimyasal indirgenmesi reaksiyonunun SOD enzimi tarafindan engellenmesinin spektrofotometrik olarak belirleme esasına dayanır. Reaksiyon karışımı (3 mL); 50 mM KH $\mathrm{PO}_{4}(\mathrm{pH}: 7.8), 13 \mathrm{mM}$ metiyonin, $63 \mu \mathrm{M}$ $\mathrm{NBT}, 13 \mu \mathrm{M}$ riboflavin ve $0.1 \mathrm{mM}$ EDTA içermektedir. Aktivite ölçümü için $3 \mathrm{~mL}$ spektrofotometre küvetine 
yukarıdaki riboflavin içermeyen reaksiyon karışımdan 2,58 mL alınmış ve üzerine $30 \mu \mathrm{L}$ enzim ekstraktı pipetlendi. Reaksiyon, tüp üzerine $13 \mu \mathrm{M}$ 'ık riboflavin çözeltisinden $390 \mu \mathrm{L}$ pipetlenip karıştırıldıktan hemen sonra, beyaz bir ışık kaynağı önüne yerleştirmek suretiyle başlatıldı. Tüp, ışık kaynağının karşısında $15 \mathrm{dk}$. tutulur ve reaksiyon ışık kaynağının kapatımasıyla durduruldu. 15 dk. içerisinde NBT'nin renk açıma yoğunluğu 560 nm'de köre karşı okunur. Kör; aynı işlemin enzimsiz örneğinden oluşmaktadır. SOD aktivitesinin 1 ünitesi, 560 nm'de gözlenen NBT indirgenmesinin \%50 inhibisyonuna neden olan enzim miktarı, 1 enzim ünitesi olarak kabul edilir ve sonuçlar $g$ yaprak başına düşen enzim ünitesi (U.g $g^{-1}$ taze ağırlık) olarak okundu (Agarwal ve Pandey, 2004).

\subsection{0. İstatistiksel analiz}

Çalışma içerisinde sunulacak sonuçlar, her bir uygulamadan üç örnek ( 3 paralel) ve her bir örnekten 3 tekerrür yapıldıktan sonra elde edilecek 9 değerin ortalaması olacaktır. Sonuçların karsılaştıııması, SPSS 17.0 paket programı kullanılarak tek yönlü varyans analizi (ANOVA) ile yapılacakve istatistik anlamlar, 0.05 hata seviyesinde Duncan'ın Çoklu Karsılastırma Testi kullanılarak belirlenmiştir.

\section{Sonuçlar ve Tartışma}

\subsection{Klor dioksitin çimlenme oranı ve fizyolojik parametreler üzerine etkisi}

Petri kaplarına ekim işlemi günlük olarak takip edilmiş ve 5. Günün sonunda toplam çimlenme yüzdeleri, kök uzunlukları ve yaş-kuru ağırlıkları hesaplanmıştır. Tüm bu işlemler sonucunda tablo incelendiğinde klor dioksitin $\left(\mathrm{ClO}_{2}\right)$ her iki konsantrasyonu kontrole göre çimlenme üzerinde herhangi bir inhibisyona neden olmamıştır (Tablo 1). Bununla birlikte $50 \mathrm{mg} / \mathrm{L} \mathrm{ClO} 2$ konsantrasyonu kök uzunluğunu $\% 6.65$ oranında artırırken $100 \mathrm{mg} / \mathrm{L} \mathrm{ClO}_{2}$ konsantrasyonu ise herhangi bir değişiklik meydana getirmemiştir. Çimlenen buğday fidelerinin yaş-kuru ağırlıklarında $\mathrm{ClO}_{2}$ in her iki konsantrasyonu önemli ölçülerde artışlara neden olmuştur. Yaş ağırlıklar kontrole göre $50 \mathrm{mg} / \mathrm{L} \mathrm{ClO}_{2}$ grubunda \%29.7 ve $100 \mathrm{mg} / \mathrm{L} \mathrm{ClO}$ grubunda ise \%39.18 oranında artmıştır. Benzer şekilde fidelerin kuru ağırlık miktarlarında da $\mathrm{ClO}_{2}$ uygulanmış gruplarda önemli oranlarda artışlar sağlanmıştır. Kontrol grubu ile kıyaslandığında fidelerin kuru ağırlıkları $50 \mathrm{mg} / \mathrm{L} \mathrm{ClO}{ }_{2}$ grubunda $\% 16.6$ ve $100 \mathrm{mg} / \mathrm{L} \mathrm{ClO}{ }_{2}$ grubunda ise $\% 33.3$ oranında artmıştır.

Tablo 1. Farklı $\mathrm{ClO}_{2}$ konsantrasyonlarının çimlenme oranları (\%), fide köklerinin uzunlukları $(\mathrm{cm})$ ve yaş-kuru ağırlıkları (g) üzerine etkisi.

\begin{tabular}{|c|c|c|c|c|}
\hline Konsantrasyonlar & Çimlenme oranı (\%) & Kök uzunluğu (cm) & Yaş ağırlık (g) & Kuru ağırlık (g) \\
\hline Kontrol & $99.33 \pm 0.1 \mathrm{a}$ & $12.47 \pm 0.3 b$ & $0.74 \pm 0.06 c$ & $0.06 \pm 0.002 c^{*}$ \\
\hline $50 \mathrm{mg} / \mathrm{L} \mathrm{ClO}_{2}$ & $100 \pm 0.0 a$ & $12.40 \pm 0.2 b$ & $0.96 \pm 0.09 b$ & $0.07 \pm 0.001 b$ \\
\hline $100 \mathrm{mg} / \mathrm{L} \mathrm{ClO} 2$ & $99.33 \pm 0.1 a$ & $13.33 \pm 0.4 a$ & $1.03 \pm 0.12 a$ & $0.08 \pm 0.002 a$ \\
\hline
\end{tabular}

*Bir sütun içinde aynı harflerin bulunduğu gruplar arasındaki farklılıklar $\mathrm{P}<0.05$ önem seviyesine göre anlamsızdır. 


\subsection{Klor dioksitin lipid peroksidasyon ve reaktif oksijen türleri üzerine etkisi}

Her iki $\mathrm{ClO}_{2}$ uygulamasıda kontrol grubuna göre buğday bitkisinin köklerinde lipid peroksidasyonun bir indikatörü olan malondialdehit (MDA) miktarlarında önemli azalmalara neden olmuştur. Kontrol bitkilerinin köklerinde MDA miktarları 1.39 nmol.g-1 olarak ölçülürken, bu değer $50 \mathrm{mg} / \mathrm{L} \mathrm{ClO} 2$ ve $100 \mathrm{mg} / \mathrm{L} \mathrm{ClO}_{2}$ uygulamalarıyla köklerde sırasıyla 0.95 ve 0.79 nmol.g-1'ye kadar azalmışır (Tablo 2). Buna göre her iki $\mathrm{ClO}_{2}$ uygulaması kontrol ile kıyaslandığında MDA miktarını sırasıyla \%31.65 ve \%43.16 gibi önemli $(P<0.05)$ oranlarda düşürmüştür. Tüm gruplardaki bitkilerin köklerindeki MDA miktarları tabloda verilmiştir (Tablo 2).

Kontrol bitkilerinin köklerinde hidrojen peroksit $\left(\mathrm{H}_{2} \mathrm{O}_{2}\right)$ ve süperoksit anyonu $\left(\mathrm{O}_{2} \cdot{ }^{*}\right)$ gibi reaktif oksijen

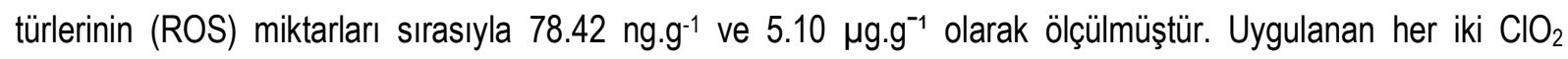
konsantrasyonları kontrole göre $\mathrm{H}_{2} \mathrm{O}_{2}$ miktarlarında önemli bir değişikliğe neden olmamıştır. Ancak $50 \mathrm{mg} / \mathrm{L} \mathrm{ClO}_{2}$ uygulaması $\mathrm{O}_{2} *$ miktarında \%18.62 oranında artıırken $100 \mathrm{mg} / \mathrm{L} \mathrm{ClO}$ uygulaması ise $\mathrm{O}_{2} \cdot$ miktarında \% 7.84 oranında azalmaya neden olmuştur. Tüm gruplardaki bitkilerin köklerindeki $\mathrm{H}_{2} \mathrm{O}_{2}$ ve $\mathrm{O}_{2}$ - miktarları tabloda verilmiştir (Tablo 2).

Tablo 2. Farklı $\mathrm{ClO}_{2}$ konsantrasyonlarının buğday bitkisi köklerinde $\mathrm{MDA}, \mathrm{H}_{2} \mathrm{O}_{2}$ ve $\mathrm{O}_{2} \cdot$ miktarı üzerine etkisi.

\begin{tabular}{|c|c|c|c|}
\hline Konsantrasyonlar & MDA (nmol.g-1) & Hidrojen Peroksit $\left(\mathrm{ng} \mathrm{g}^{-1}\right)$ & Süperoksit anyonu $\left(\mu g . g^{-1}\right)$ \\
\hline Kontrol & $1.39 \pm 0.4 c$ & $78.42 \pm 2.1 \mathrm{a}$ & $5.10 \pm 0.3 b^{*}$ \\
\hline $50 \mathrm{mg} / \mathrm{L} \mathrm{ClO}_{2}$ & $0.95 \pm 0.2 b$ & $77.70 \pm 3.4 a$ & $6.05 \pm 0.4 c$ \\
\hline $100 \mathrm{mg} / \mathrm{L} \mathrm{ClO}{ }_{2}$ & $0.79 \pm 0.1 a$ & $76.98 \pm 4.2 a$ & $4.70 \pm 0.1 \mathrm{a}$ \\
\hline
\end{tabular}

*Bir sütun içinde aynı harflerin bulunduğu gruplar arasındaki farklılıklar $\mathrm{P}<0.05$ önem seviyesine göre anlamsızdır.

\subsection{Klor dioksitin antioksidan enzimler türleri üzerine etkisi}

Süperoksit dismutaz (SOD) enziminin aktivite düzeylerinin kontrol ve $\mathrm{ClO}_{2}$ uygulamalarında farklılık gösterdiği görülmüştür (Tablo 3). Kontrole göre $50 \mathrm{mg} / \mathrm{L} \mathrm{ClO} 2$ uygulanan bitkilerin köklerinde $\mathrm{SOD}$ aktivitesi \%36.8'lik önemli bir artışa $(\mathrm{P}<0.05)$ neden olmuştur (Tablo 3). Benzer şekilde $100 \mathrm{mg} / \mathrm{L} \mathrm{ClO} 2$ uygulamasında kontrole göre SOD aktivitesinde \%59.12'lik önemli bir artış meydana gelmiştir $(P<0.05)$. Tüm gruplardaki bitkilerin köklerindeki SOD değişimleri tabloda verilmiştir (Tablo 3).

Buğday bitkisinin köklerinde peroksidaz (POD) aktivitesi kontrole grubuna göre $\mathrm{ClO}_{2}$ uygulamalarında önemli değişimler meydana gelmiştir (Tablo 3). Kontrol bitkisinin yapraklarında POD aktivitesi $5832.5{\mathrm{U} . \mathrm{mg}^{-1}}^{-1}$ taze ağırlık iken, 50 mg/L ClO 2 uygulamasıyla bu değer \%58' lik' bir azalışla $2445{\mathrm{U} . \mathrm{mg}^{-1}}^{1}$ taze ağırlık olarak belirlenmiştir.

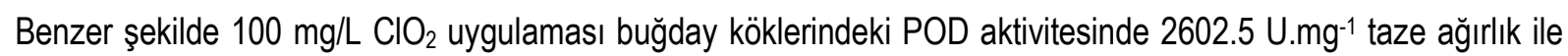
$\% 55^{\prime}$ lik' bir azalışa neden olmuştur. 
Tablo 3. Farklı $\mathrm{ClO}_{2}$ konsantrasyonlarının buğday bitkisi köklerinde $\mathrm{SOD}$ ve $\mathrm{POD}$ aktiviteleri üzerine etkisi.

\begin{tabular}{lll} 
Konsantrasyonlar & SOD (U.mg-1 taze ağırlık) & POD (U.mg-1 taze ağırlık) \\
\hline Kontrol & $5.92 \pm 0.3 \mathrm{a}$ & $5832.50 \pm 23.4 \mathrm{c}^{*}$ \\
$50 \mathrm{mg} / \mathrm{L} \mathrm{ClO}_{2}$ & $8.10 \pm 0.8 \mathrm{~b}$ & $2445 \pm 18.6 \mathrm{a}$ \\
$100 \mathrm{mg} / \mathrm{L} \mathrm{ClO}_{2}$ & $9.42 \pm 0.6 \mathrm{c}$ & $2602.50 \pm 14.8 \mathrm{~b}$
\end{tabular}

${ }^{*}$ Bir sütun içinde aynı harflerin bulunduğu gruplar arasındaki farkllıklar $\mathrm{P}<0.05$ önem seviyesine göre anlamsızdır.

Çalışmamızda insanoğlunun kültüre aldığı en eski tarla bitkilerinden biri olan buğday (Triticum aestivum L.) kullanılmışır. Dünyada tahıl bitkileri içerisinde buğday en geniş ekim alanı ve üretime sahiptir. Günümüzde zengin besin maddesi içeriği nedeniyle özellikle insan beslenmesinde kullanılan buğday, yüksek verim alınabilen bir tarla bitkisi olarak değerlendirilmektedir. Çalışmamızda kullandığımız Gerek-79; kışlık, soğuğa ve kurağa dayanıklı olup, kardeşlenmesi yüksek, sarı ve kahverengi paslara toleranslı, kara pasa orta hassas olan bir ekmeklik buğday çeşittir. Suların dezenfeksiyonunda kullanılan klor dioksitin $\left(\mathrm{ClO}_{2}\right)$ tarımsal sulara karışabilmekte ve buğday yetiştiriciliği alanlarına ulaşabilmektedir. Bundan dolayı $\mathrm{ClO}_{2}$ 'a maruz kalan buğday bitkilerinde nasıl bir fizyolojk ve biyokimyasal değişim olacağı ve bitkinin bundan nasıl etkilendiğini tespit etmek son derece önem arz etmektedir. $\mathrm{Bu}$ çalışmada ilkkez buğday bitkisine çimlenme aşamasında farkı konsantrasyonlarda $\mathrm{ClO}_{2}$ uygulamaları yapılarak olası fizyolojik ve biyokimysal parametrelerdeki değişimler analiz edilmiştir.

$\mathrm{ClO}_{2}$ uygulaması buğday tohumlarının çimlenmelerinde herhangi bir inhibisyona neden olmamıştır. Bununla birlikte kök uzunluğu ve yaş-kuru ağırlıklarında da inhibisyona da neden olmadığı gibi bilakis bu parametrelerde artışa bile neden olduğu tespit edilmiştir (Tablo 1). $\mathrm{Bu}$ durum $\mathrm{ClO}_{2}$ in tohum çimlenme aşamasında fizyolojik bir inhibisyona neden olmadığını göstermektedir. Daha önce yapılan bir çalışmada; arpa bitkisinin çimlenme aşamasında $\mathrm{ClO}_{2}$ 'in uygulamasının çimlenme oranını etkilemediği, yaş ağırlığı ise önemli oranda artırdığı tespit edilmiştir (Wang vd., 2019). Çalışmamızda elde edilen sonuçlar daha önce yapılan ilgili çalışmanın sonuçları ile uyumlu olduğu görülmektedir. Bu olumlu durum özellikle buğdayın depolanması esnasında zararlara neden olan mikroorganizmların önlenmesi için $\mathrm{ClO}_{2}$ in antimikrobiyal ajan olarak kullanılabilme imkanını tanımaktadır. Bunun neticesinde depolama aşamalarında meydana gelen verim kayıplarının önüne geçilebilir.

Hücre membranı, hücreleri ve organellerini içeren seçici geçirgen bir bariyerdir, bu seçici-geçirgenlik hücre veya organellerin iç ve dış ortamı arasındaki maddelerin geçişini sağlar. Benzer şekilde sinyal aktarımı ve bazı maddelerin sentezini yaparak hücreler için fiziksel bağlantıyı da sağlar (Wang vd., 2019). Olumsuz şartlarda bitki hücrelerinde aşırı reaktif oksijen türlerinin oluştuğu belirtilmiştir. Miktarı artan ve biriken ROS'lar, hücre zarlarındaki doymamış yağ asitlerini oksitleyerek lipidlerinin peroksidasyonuna neden olur. Bunun neticesinde hücre zarı zarar görür, seçiciliği bozulur, böylece sitoplazmadan elektrolitlerin sızması artar. Bu nedenle, MDA içeriğinin artması zar geçirgenliği ve hücre zarı hasar görme oranı olarak değerlendirilir. Hidrojen peroksit $\left(\mathrm{H}_{2} \mathrm{O}_{2}\right)$; bitkilerde özellikle peroksizom, mitokondri ve kloroplastlardaki metabolik etkinlikler sonucunda oluşan bir oksidan üründür. Süperoksit anyonu $\left(\mathrm{O}_{2}^{*}\right)$, stres şartlarında içsel seviyesi artan ve hücrelerde önemli hasarlara neden olan bir radikaldir. $\mathrm{Bu}$ radikalin lipid peroksidasyonu, membran hasarı, hücresel toksisite ve DNA'daki tek zincir kırımalarına sebep olduğu belirtilmiştir (Asada 2006). Buğday bitkisinin çimlenme aşamasında uygulama yapılan $\mathrm{ClO}_{2}$ 'in özellikle MDA 
miktarını düşürmesi ve aynı zamanda $\mathrm{H}_{2} \mathrm{O}_{2}$ miktarında ise artışa neden olmaması $\mathrm{ClO}_{2}$ 'un çimlenme aşamasında buğday kökleri üzerinde herhangi bir oksidatif hasar oluşturmadığını göstermektedir. $\mathrm{O}_{2} \cdot$ - miktarının sadece $50 \mathrm{~m} / \mathrm{L}$ konsantrasyonunda belirli oranda artış meydana gelmiştir. Ancak MDA sonuçları incelendiğinde meydana gelen bu artışın hücre zarında oksidatif zarara neden olmadığı anlaşımaktadır. Benzer şekilde arpa tohumlarının çimlenme aşamasında uygulanan $\mathrm{ClO}_{2}$ 'in MDA oluşumunda artışa neden olmadığı tespit edilmiştir (Wang vd., 2019). İlgili çalışmanın sonuçları ile bizim çalışmanın sonuçları arasında iyi bir uyum görülmektedir. $\mathrm{ClO}_{2}$ 'nin çimlenme aşamasında oksidatif hasara neden olmaması son derece önemli bir gösterge olup buğday bitkileri üzerine $\mathrm{ClO}_{2}$ 'in olumlu etkisinin olabilme intimalini daha da artırmaktadır.

$\mathrm{SOD}$ ve $\mathrm{POD}$ bitkilerde oksidatif hasarın önlenmesi ile ilgili iki ana antioksidan enzimdir. $\mathrm{H}_{2} \mathrm{O}_{2}$ ve $\mathrm{O}_{2}$ “ gibi reaktif oksijen türleri hasarından bitki hücrelerini etkili bir SOD ve $\mathrm{POD}$ savunma hattı koruyabilir. Deneysel sonuçlarımı hem $50 \mathrm{mg} / \mathrm{L}$ hem de $100 \mathrm{mg} / \mathrm{L} \mathrm{ClO}$ uygulamaları SOD aktivitesini önemli ölçüde artırırken, POD aktivitesini azaltmıştır (Tablo 3). POD aktivitesindeki azalmanın nedeni substratı olan $\mathrm{H}_{2} \mathrm{O}_{2}$ 'in artmaması olabilir. Özellikle SOD aktivitesindeki artış, antioksidan kapasitede bir artışa ve bununla birlikte MDA ve ROS konsantrasyonlarında bir azalmaya yol açtı. Benzer şekilde daha önce yapılan bir çalışma da antioksidan enzim aktivitelerinde olumlu etkiler yaptığı belirtilmiştir (Wang vd., 2019). Bu durumda oksidatif hasarın oluşmadığının diğer bir göstergesidir.

\section{Sonuç}

Son yıllarda özellikle içme sularının dezenfeksiyonunda kullanımı giderek artan $\mathrm{ClO}_{2}$ 'in tarımsal sulara da karıştığı ve bu durumda bitkisel üretim süreci üzerinde nasıl bir etki yapacağı belirsizdir. Bu çalışmada elde edilen sonuçlara göre $\mathrm{ClO}_{2}$ in buğdayın çimlenme aşamasında kök kısımlarında herhangi bir inhibisyona ve oksidatif hasara neden olmadığı belirlenmiştir. İyi bir dezenfaktan olan $\mathrm{ClO}_{2}$ in özellikle buğdayın depo koşullarda meydana gelen mikrobiyal kaynaklı hastalık ve kayıplarını azaltmada kullanma potansiyeli olabilir. $\mathrm{ClO}_{2}$ 'in buğday bitkilerinin çimlenme aşamasındaki etkisi ile ilgili ilk olan bu çalışmanın sonuçlarının etkinliğini ve kullanma potansiyeli için daha ileri çalışmalara gereksinim duyulmaktadır.

\section{Çıkar Çatışmaları}

Yazarlar çıkar çatışması olmadığııı beyan ediyor

Bu makale Doç.Dr. Nevzat Esim danışmanlığında hazırlanan yüksek lisans tezinden üretilmiştir.

\section{Kaynaklar}

Agarwal, S., \& Pandey, V. (2004). Antioxidant enzyme responses to $\mathrm{NaCl}$ stress in Cassia angustifolia. Biologia Plantarum, 48(4), 555-560.

Ananieva, E. A., Alexieva, V. S., \& Popova, L. P. (2002). Treatment with salicylic acid decreases the effects of paraquat on photosynthesis. Journal of Plant Physiology, 159(7), 685-693.

Angelini, R., \& Federico, R. (1989). Histochemical evidence of polyamine oxidation and generation of hydrogen peroxide in the cell wall. Journal of Plant Physiology, 135(2), 212-217. 
Anonim. (2013). http://www.trakkulup.net/haberler-desteklemeler/bugday-ve-bugdaytarimi-hakkinda-genelbilgiler2013/ Erişim tarihi: 28.09.2013.

Asada, K. (2006). Production and scavenging of reactive oxygen species in chloroplasts and their functions. Plant Physiology, 141(2), 391-396.

Esim, N. (2011). Nitrik oksitin mısır da (Zea mays) düşük sıcaklık stresine toleransı üzerine etkisi. Doktora Tezi, Atatürk Üniversitesi Fen Bilimleri Enstitüsü, Erzurum.

Fisher, P. (2011). Water Treatment Guidelines. Water Education Alliance For Horticulture. Gainesville: University of Florida IFAS Extension.

Gómez-López, V. M., Rajkovic, A., Ragaert, P., Smigic, N., \& Devlieghere, F. (2009). Chlorine dioxide for minimally processed produce preservation: a review. Trends in Food Science \& Technology, 20(1), 17-26.

Hong, C. X. (2014). Component analyses of irrigation water in plant disease epidemiology. Biology, detection and management of plant pathogens in irrigation water. St. Paul: The American Phytopathological Society.

Hong, C. X., \& Moorman, G. W. (2005). Plant pathogens in irrigation water: challenges and opportunities. Critical Reviews in Plant Sciences, 24(3), 189-208.

Liu, Y., Wu, R., Wan, Q., Xie, G., \& Bi, Y. (2007). Glucose-6-phosphate dehydrogenase plays a pivotal role in nitric oxide-involved defense against oxidative stress under salt stress in red kidney bean roots. Plant and Cell Physiology, 48(3), 511-522.

Newman, S. (2004). Disinfecting irrigation water for greenhouse. Paper presented at the 20th annual conference on pest management on ornamentals, San Jose: 20-22 Feb 2004.

Parry, D. W., Jenkinson, P., \& McLeod, L. (1995). Fusarium ear blight (scab) in small grain cereals-a review. Plant Pathology, 44(2), 207-238.

Scarlett, K., Collins, D., Tesoriero, L., Jewell, L., van Ogtrop, F., \& Daniel, R. (2016). Efficacy of chlorine, chlorine dioxide and ultraviolet radiation as disinfectants against plant pathogens in irrigation water. European Journal of Plant Pathology, 145(1), 27-38.

Wang, R., Chen, B., Wang, T., Li, P., \& Ding, F. (2019). Effects of chlorine dioxide on the germination, oxidative metabolism and growth of barley seedlings (Hordeum vulgare L.). Scientific Reports, 9(1), 1-8.

Yang, X., Copes, W. E., \& Hong, C. (2013). Phytophthora mississippiae sp. nov., a new species recovered from irrigation reservoirs at a plant nursery in Mississippi. Journal of Plant Pathology and Microbiology, 4(6), 180. Doi: 10.4172/2157-7471.1000180 